\title{
Staff responsiveness to transformation initiatives and diversity at a South African university
}

\author{
J.P.R. Joubert \& N. Martins \\ University of South Africa martin@unisa.ac.za
}

\begin{abstract}
South African organisations and particularly institutions of higher learning have been confronted with workforces that increasingly reflect the diversity of the South African population. This changing workforce composition implies that the multitude of individual and cultural differences and similarities become increasingly apparent among employees. These differences and similarities can be disruptive and may lead to disharmony, but if managed appropriately, they can also result in increased vigour, stimulation and energy. The importance of workforce diversity in especially a university environment cannot be over-emphasised, as these positive consequences are conducive and sustain universities in their role to expand knowledge that benefits the communities within which they operate. Various transformative initiatives to address diversity, have been devised and implemented, but the impact needs to be measured and assessed to enable leaders to manage diverse workforces more effectively. This article therefore aims to firstly, statistically identify the underlying dimensions of diversity within the largest university in Africa, namely the University of South Africa (Unisa). The responsiveness of university staff members who attended transformative diversity-training workshops are secondly investigated by comparing their responses to that of a matched sample of non-participating staff members. These workshops aimed to sensitise academic, administrative and professional staff at middle-management level to the new realities of an increasing diverse workforce. It is evident that the workshops had a positive impact and that they could be described as successful. The importance of noting that diversity interventions not only entail creating awareness of diversity issues, but also applying the principles of diversity management on a continuous basis, is underscored in this article.
\end{abstract}

Keywords: Diversity, diversity management, transformation, factor analysis

\section{Introduction}

Since the new government introduced an agenda of change and transformation in 1994, universities in South Africa have had to contend with rapid and imposing change. Institutions of higher education furthermore continue to grapple with transformation issues due to additional pressure from stakeholders, including students, the business community and donors.

Universities are key agents in this agenda for change and transformation. They provide places where the new democracy's idealism finds expression, its leaders are skilled and its ideas are formed. Yet the higher education system inherited by universities was inherently unequal, and in many respects outdated and not in step with the emerging ideals of the post-apartheid democratic South Africa. This meant that 
universities' visions, missions and strategies had to be about dealing with the legacy of the past in addition to shaping and preparing themselves to embrace the future in a global world.

The transformation of universities' staff composition reflecting the diversity of the South African population can, according to Nieuwmeijer (2001), impact both positively and negatively by stimulating higher levels of energy while also leading to discord. It is for this reason that the effective management of staff diversity becomes crucial to influence employee attitudes, the recruitment of human resources, creativity, innovation and productivity within the institution (Kreitner and Kinicki, 2007). This dynamic has been investigated further by Tjale (2005), who found a positive and strong relationship between diversity management and organisational climate. However, if a university's management are not informed of staff perceptions of and attitudes towards diversity and these perceptions and attitudes are neither managed nor valued, the climate of a university could, according to Human, Bluen and Davies (1999), be infested with a lack of dignity and self-respect. In this regard, important aspects to consider are barriers restricting any transformation towards diversity, such as, among others, the autonomy of universities and the influence of international trends. Some universities have been very conscious of these 'restraints' and become very defensive and protective of university autonomy and academic freedom amassed since medieval times, while other universities have embraced change and thereby traded essential values and traditions for transient gains. This quandary necessitates that universities' management act in a way that takes cognisance of the changing diversity in staff while conforming to the fundamental values that express the ethos and ideals of what a university is.

To assist in addressing this quandary, Unisia's management rightfully posed the question, as any South African university leadership should, of how its staff perceived transformative initiatives, resultant increased staff diversity and the management thereof. Because diversity management is a relatively new field in the broader South African business environment and within universities in particular, and given that the managing of workforce diversity has developed as a business imperative, an article reflecting on an investigation into the underlying conceptual structure of diversity and the attitude of Unisa staff towards diversity is justified. This article consequently firstly discusses the concept of diversity and diversity management as expressed within the Unisa environment. This is followed by a report of initiatives taken to address institutional change and specifically diversity. In this regard, an external service provider was appointed to not only assist in managing diversity initiatives and promoting tolerance among staff and the broader university community, but also to ensure that Unisa's values of social justice and fairness as well as excellence with integrity find expression in the day-to-day activities of the university. One such initiative was in the form of capacity-building workshops, offered to permanent members of staff at different post levels, focusing on middle management. The staff's perceptions of and attitudes towards diversity was moreover investigated by conducting an empirical comparative study and analysing the response of staff who attended and staff who did not attend these workshops. 
The focus on diversity management requires that the concept of diversity be clearly explicated and defined.

\section{Defining diversity}

Diversity has been defined from various perspectives. Narrow definitions tend to reflect employment equity law, and define diversity in terms of race, gender, ethnicity, age, national origin, religion and disability (Wheeler, 1994). Broad definitions include sexual orientation, values, personality characteristics, education, language, physical appearance, marital status, lifestyle, beliefs and background characteristics such as geographic origin, tenure with the organisation and economic status (Thomas, 1992; Triandis, 1994). According to Kreiter and Kinicki (2007), diversity represents individual differences and similarities that exist among people. Kreiter and Kinicki's definition of diversity is further explicated by the four layers of diversity, as reflected in Table 1.

Table 1: Diversity layers

\begin{tabular}{|l|l|}
\hline Layer & Description \\
\hline Personality & $\begin{array}{l}\text { This describes the stable set of characteristics that } \\
\text { establishes a person's identity. }\end{array}$ \\
\hline Internal dimensions & $\begin{array}{l}\text { These are characteristics that strongly influence people's } \\
\text { attitudes, perceptions and expectations of others. These } \\
\text { include differences in, among others, age, race, gender, } \\
\text { sexual orientation and ethnicity. }\end{array}$ \\
\hline External dimensions & $\begin{array}{l}\text { These dimensions are personal traits over which a } \\
\text { person can assert a certain amount of control or } \\
\text { influence. These include differences in, among others, } \\
\text { income, education, work experience and } \\
\text { geographical location (where born/currently living). }\end{array}$ \\
\hline $\begin{array}{l}\text { Organisational } \\
\text { dimensions }\end{array}$ & $\begin{array}{l}\text { These dimensions pertain to the organisation and } \\
\text { include differences in work field, division or unit, } \\
\text { seniority, management status and functional level. }\end{array}$ \\
\hline
\end{tabular}

(Adapted from KreiterandKinicki, 2007)

The earlier definition by Kandola and Fullerton (1998) provides greater clarity of the Kreiter and Kinicki definition by explaining diversity as describing the visible and nonvisible differences that exist between people. Visible differences include personal characteristics such as sex, age, background, race, disability and work style. Less visible differences include people's attitudes, perceptions and expectations. 
By restructuring the diversity concepts reflected in Table 1, diversity can be categorised into primary and secondary dimensions, as suggested in the earlier work of Griggs (1995). Primary dimensions of diversity are those human differences that are inborn and exert an important impact on our early socialisation and have an ongoing impact throughout our lives. The six primary dimensions include age, ethnicity, gender, physical abilities/qualities, race and sexual orientation. Griggs also concluded that these primary dimensions shape people's basic self-image and have great influence on how people view the world. The secondary dimensions of diversity are those that can be changed and include, but are not limited to, educational background, geographic location, income, marital status, parental status, religious beliefs and work experience.

It should in this regard be noted that the essence and spirit of the Employment Equity Act No. 55 of 1998 are devoted to coercing companies to create a workforce profile that closely represents the demographic realities (primary dimension) of South Africa. However, this alone does not lead to an organisational climate that embraces diversity as a strategic asset, compared to a political imperative. Secondary differences are significant in shaping people, but they are to some extent shape able in return, because people have some measure of control over them.

This article focuses on diversity in the broadest sense, which includes all the different characteristics that make one individual different from another. The major purpose for defining diversity so broadly is that it is all-inclusive and recognises everyone as part of the diversity that should be valued (Griggs, 1995). A broad definition of diversity goes beyond protected-class differences, because all employees bring their differences, including a variety of group identity differences, to the workplace (Johnson, 1995). A broad definition moves workplace diversity issues beyond "us versus them' to focus on using and maximising diversity to accomplish both individual and organisational goals. It provides an overarching goal for a unifying focus.

\section{Diversity management}

One of the strategies to accelerate the change process is affirmative action, yet affirmative action on its own is not the whole answer. It is essential that the diversity created by affirmative action be effectively managed. The concept of 'managing diversity' has grown out of human resources management and represents a movement away from traditional equal opportunities policies and practices. It is premised on recognition of diversity and differences as positive attributes of an organisation, rather than as problems to be solved. (Thompson 1998, 195).

Roosevelt Thomas $(1990,107)$ defines managing diversity as "not controlling or containing diversity but enabling every member...to perform to his or her potential". This holds implications for how institutions of higher education will handle this process of change, for as Havenga (1993:9) points out,

"diversity starts with a realisation of diverse interests...It is clear, unlike affirmative action which is a process for creating diversity, that the very essence of the organisation and its culture must be re-negotiated and re-conceptualised from a perspective other than the dominant culture". 
These definitions express a distinctive approach to employment management, which seeks to achieve competitive advantage through the strategic deployment of diversity in the workforce.

Kandola and Fullerton (1998), in describing the concept of managing diversity, reiterate accepting that differences exist between employees, that these differences will create a productive environment in which everybody feels valued, where their talents are being fully utilised and within which organisational goals are met and that it concerns not only personnel and human resource practitioners, but all employees, especially managers within an organisation.

Thomas and Ely $(1999,139)$ mentioned three paradigms that characterise diversity-management efforts. The first involves "discrimination-and-fairness", which is based on the recognition that discrimination is wrong and idealises conformism. The second, "access-and-legitimacy", celebrates difference and seeks to target diverse individuals and groups, but can leave employees feeling marginalised or exploited. The third is the "learning-and-effectiveness" paradigm, which incorporates aspects of the first two paradigms while connecting diversity to the organisation's work. The main emphasis of this third paradigm is therefore integration. Like the fairness paradigm, it promotes equal opportunity for all individuals, and like the access paradigm, it acknowledges cultural differences among people and recognises value in those differences. Yet this paradigm for managing diversity lets the organisation internalise differences among employees so that it learns and grows because of them.

Researchers rarely collect and analyse data without an a priori idea about how the variables are related. A review of relevant literature indicated that when attempting to measure the success of diversity-awareness initiatives, a number of organisational dimensions should be considered and assessed to determine the effect of the initiative. After investigating a number of studies on diversity (Cavaleros, Van Vuuren and Visser, 2002; Düweke, 2004; Strydom and Erwee, 1998; Tjale, 2005), six dimensions were identified and are reflected in Table 2.

Table 2: Diversity dimensions

\begin{tabular}{|l|l|}
\hline Dimension & Description \\
\hline Diversity perceptions & $\begin{array}{l}\text { Perceptions relating to diversity in the } \\
\text { workplace. }\end{array}$ \\
\hline Interpersonal issues & $\begin{array}{l}\text { Relationship issues between employees due to } \\
\text { primary and secondary dimensions of diversity. }\end{array}$ \\
\hline $\begin{array}{l}\text { Diversity and } \\
\text { employment equity }\end{array}$ & $\begin{array}{l}\text { Impact of a diverse workforce on performance and } \\
\text { the contribution of employment equity to the } \\
\text { success of the institution. }\end{array}$ \\
\hline
\end{tabular}




\begin{tabular}{|l|l|}
\hline $\begin{array}{l}\text { Workforce diversity and } \\
\text { inclusion }\end{array}$ & $\begin{array}{l}\text { Respecting, accommodating, communicating and } \\
\text { valuing others regardless of race, gender, religion, } \\
\text { sexual orientation and background. }\end{array}$ \\
\hline Diversity initiatives & $\begin{array}{l}\text { Intervening in diversity-related matters, support from } \\
\text { management in diversity-related problems and } \\
\text { encouraging subordinates to participate in diversity } \\
\text { initiatives. }\end{array}$ \\
\hline Barriers to diversity \\
initiatives & $\begin{array}{l}\text { The role of barriers such as stereotypes, fear of } \\
\text { discrimination, the work environment, change and } \\
\text { communication on diversity management. }\end{array}$ \\
\hline
\end{tabular}

The questions whether the diversity dimensions in Table 2 also reflect among Unisa staff and whether the training interventions have changed, diversity- related perceptions are also addressed in this article.

\section{Diversity training}

Although organisations use a broad range of initiatives in their efforts to value and manage diversity, training interventions are widely used. The definition for diversity training varies and is heavily influenced by the way the concept of diversity is understood in the organisation (Wheeler, 1994). According to Wheeler, from the broad corporate perspective, diversity training is defined as raising personal awareness about individual differences in the workplace and how those differences inhibit or enhance the way people work together and get work done. There are many kinds of diversity-training programmes; however, the literature shows that diversity training is often grouped into three types of training interventions, namely awareness-based, skills-based and integration into other types of training (Carnevale and Stone, 1995; Wheeler, 1994). The three different approaches may overlap and can reinforce each other, but are not necessary sequential.

The training intervention employed at Unisa was awareness-based, aiming at heightening awareness of diversity issues and revealing staffs' unexamined assumptions and tendencies to stereotype. The interventions were in the form of workshops designed to increase employee knowledge and sensitivity to diversity issues. Training focused on diversity and diversity management, barriers to diversity management, diversity initiatives, workforce diversity and inclusion and interpersonal dimensions of diversity. An evaluation of these interventions, such as reported in this article, provides an opportunity to assess the effectiveness of the diversity interventions. 
Diversity assessment is critical for the future of organisations and their workforce. Simons (1992) mentions that assessment assists in setting priorities for diversity awareness, knowledge and skills training, provides insight into what further assessment might be needed to address the opportunities and challenges created by diversity and assesses how successful the organisation has been at transcultural thinking and behaviour.

Morrison (1992) provides guidelines for organisations to uncover their diversity issues. These guidelines suggest that managers as well as employees be directly involved in any such internal investigation. Early involvement in this phase tends to gain more support for a diversity-training strategy.

The imposed need for transformation and an ensuing diverse workforce at the university under scrutiny necessitates a brief overview of transformation at Unisa.

\section{Transformation at Unisa}

Unisia's strategic plan spells out a comprehensive agenda for directing change and organisational renewal at the university (Author unknown, 2005). This transformation agenda covers the entire spectrum of the strategic planning process, including the vision, mission, values and institutional operations. In terms of this requirement, Unisa aims to effect a seamless transition towards harmonised and coherent structures, policies, processes, systems and practices. In addition, the relevant strategy identified to address this transition was to implement change management. In particular, this strategy aimed to steer and monitor change, promote a climate of caring and tolerance, informed by staff and student satisfaction surveys, by means of a programme for culture and institutional change. This strategy finds expression in Unisia's operational planning and aims to entrench diversity, equity and excellence as Unisa hallmarks. Against this background, the management of diversity has become an important managerial, hence leadership, consideration for Unisa. In order to give effect to the latter, management embarked on a number of initiatives aimed at institutionalising the strategy mentioned above. Due to the large size and complexity of Unisa, management approved the appointment of an external service provider to assist Unisa with the development and implementation of an institutional culture-change programme.

The focus of such a programme was specifically to assist Unisa to not only manage diversity and promote tolerance among staff and between staff and students, but also to ensure that Unisa's values find expression in day-to-day activities. Such assistance was in the form of capacity-building workshops, offered to members of staff at different post-grade levels, with a special focus on middle managers. A series of diversity-appreciation and capacity-building workshops (11 in total) was organised and attended by 332 staff members at different middle-management post levels. Participation in these workshops was voluntary.

This article therefore aims to firstly statistically identify the underlying dimensions of diversity, and secondly to investigate the impact of capacity building workshops through a comparison of attendees and non-attendees. 


\section{Method}

The research approach was quantitative and descriptive in nature and a survey datacollection method was used to gather self-report descriptive information on the attitudes, behaviours and other characteristics of the Unisa population. Acrosssectional design was applied that shows how the attendee and non- attendee groups differ from one another at a point in time.

\section{Participants}

All 332 employees who participated in the change and transformation workshops were invited to participate in the audit. In addition, 548 employees who did not attend any of the workshops were purposefully selected, using a matched, quota-controlled, random sampling method. Selection was matched on quotas imposed by attendees' management post level, gender, age, population group and tenure at Unisa. Once the quotas were established, non-attendees were randomly selected using Unisia's employee database. As a result, 880 staff members were invited to participate in the survey.

\section{Data collection}

The data-collection methods involved using computer-aided telephone interviews (CATI) combined with self-administered web-based survey questionnaires. The same questionnaire was used for both data-collection methods. The number of employees targeted for CATI and web-based interviewing were the following:

- CATI interviews: 427 (332 workshop attendees and 95 non-workshop attendees)

- Web-based questionnaires: 453 (non-workshop attendees)

It should be noted that approximately 200 employees initially targeted for CATI interviews opted for self-completion of the survey via the web. The final number of questionnaires returned by the workshop and non-workshop attendees was as follows:

- Workshop attendees: 171 respondents (or $51.5 \%$ of all workshop attendees)

- Non-workshop attendees: 90 (or $16.4 \%$ of all non-workshop attendees invited to participate)

Based on these figures, the total response rate for the study was almost 30\%. Table 3 reflects the percentage distribution of the total realised sample by job level, tenure, post level, age, gender, population group and attendance of the diversity workshops. 
Table 3: Overall profile

$$
(n=261)
$$

\begin{tabular}{|l|l|l|}
\hline \multicolumn{2}{|l|}{ Demographic } & $6 \%$ \\
\hline \multirow{5}{*}{ Job level } & Executive management & $53 \%$ \\
& Administrative/professional & $24 \%$ \\
& Academic community & $17 \%$ \\
\hline \multirow{3}{*}{ Tenure } & Regional offices & $24 \%$ \\
& Less than 5 years & $19 \%$ \\
\hline Post level & $5-10$ years & $57 \%$ \\
& 10 years+ & $20 \%$ \\
& Grade 12 & $19 \%$ \\
\hline Age & Undergraduate degree & $61 \%$ \\
\hline Postgraduate degree & $7 \%$ \\
& $21-34$ & $24 \%$ \\
& $35-44$ & $45 \%$ \\
& $45-54$ & $23 \%$ \\
\hline Gender & 55 or older & $45 \%$ \\
& Female & $55 \%$ \\
\hline Population group & Male & $42 \%$ \\
& Designated & $58 \%$ \\
\hline Attendance & Non-designated & $66 \%$ \\
& Attendees & $34 \%$ \\
\hline & Non-attendees & \\
\hline
\end{tabular}

The sample mainly consisted of middle-management administrative and professional staff with 10 years or more tenure who were 45 to 54 years old and held a postgraduate qualification.

\section{Analysis}

Data were analysed quantitatively by means of SPSS (Statistics Package for Social Scientists) version 18. This section firstly reports on the reliability of the measuring instrument, secondly on the underlying structure of the diversity construct in a university context and thirdly on the impact that attendance of the workshops has had on the perceptions and attitudes of employees. 


\section{Measuring instrument}

Fifty statements were selected from a previously validated diversity questionnaire (Düweke, 2004) and where needed adapted or rephrased to reflect a university environment. These statements represent the dimensions reflected in Table 2, namely diversity perceptions, interpersonal issues, diversity and employment equity, workforce diversity and inclusion, diversity initiatives and barriers to diversity initiatives. The diversity questionnaire was administered during the first quarter of 2008. The questionnaire consisted of a five-point Likert scale consisting of the following:

$1=$ Strongly disagree

2 = Disagree

3 = Unsure/ Don' know

4 = Agree

5 = Strongly agree

To further enhance understanding of the diversity concept within a university environment, a factor analysis (extraction method: principal component analysis; rotation method: Varimax with Kaiser normalisation) was employed to uncover the basic structure underlying diversity within a university context. Principal component factor analysis was preferred due to unconfirmed theoretical perspectives on the concept of diversity and the management thereof within a university environment. During factor extraction, the shared variance of a variable is partitioned from its unique variance and error variance to reveal the underlying factor structure where only shared variance appeared in the solution.

Fabrigar, Wegener, MacCallum and Strahan (1999, 277) argue that if data are relatively normally distributed, maximum likelihood is the best choice because "it allows for the computation of a wide range of indexes of the goodness of fit of the model [and] permits statistical significance testing of factor loadings and correlations among factors and the computation of confidence intervals". If the assumption of multivariate normality is violated, as is the case with the present data, they recommend principal axis factors.

A factor solution with 14 factors was extracted. Only eigen values of plus one were considered. There is however broad consensus in the literature that this is among the least accurate methods for selecting the number of factors to retain (Velicerand Jackson, 1990) and it is suggested that the scree test be utilised to arrive at a more justifiable number of factors. This test involves examining the graph (see Figure 1) of the eigen values and looking for the natural bend or break point in the data where the curve flattens out. The number of data points above the 'break' (i.e. not including the point at which the break occurs) is usually the number of factors to retain. 


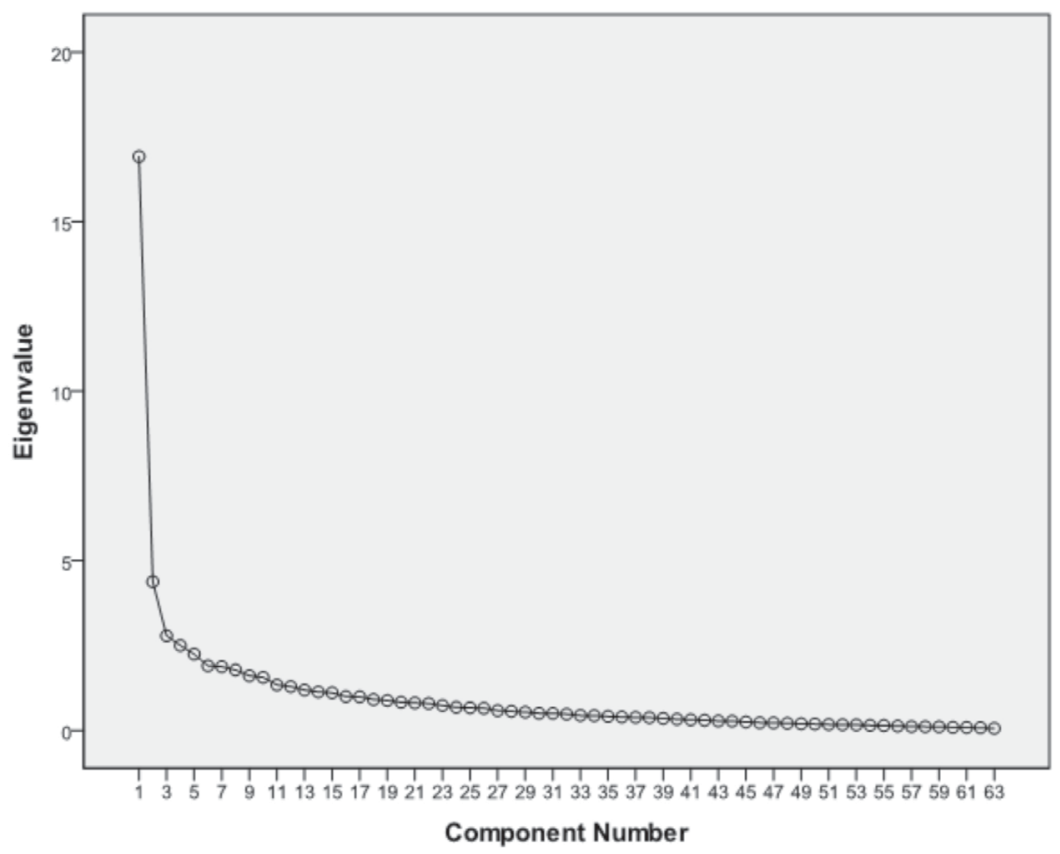

Figure 1: Screen Test

It is clear from Figure 1 that five data points can be identified above the break and that these should be included in the final factor solution. The five factors explained $45.79 \%$ of the total variance in the measurement of diversity perceptions and attitudes and can be construed as Respect, Conduct, Interaction, Impact and Ownership. The value of this analysis is that the relative importance of dimensions is ascertained, which in turn influences allocation of resources to either continue or change current diversity-management strategies.

Fourteen statements relating to respecting, valuing and accepting differences, recognising competence and fair treatment of employees irrespective of their differences contributed most to Factor 1, explaining $26.86 \%$ of the total variance (Respect). Five statements describing whether employees are treated equally regardless of race, gender, sexual orientation, age and religion displayed high factor loadings on Factor 2, explaining $6.96 \%$ of the total variance (Conduct).

Four statements concerning more open, positive and effective interaction irrespective of race group displayed high factor loadings on Factor 3, explaining 4.43\% of the total variance (Interaction). Four statements pertaining to the impact of various initiatives, including affirmative action and competence-based appointments, contributed most to Factor 4, explaining $3.98 \%$ of the total variance (Impact). Three statements relating to diversity management by considering employment equity issues when appointing staff and intervening in diversity-related matters contributed to Factor 5, explaining $3.57 \%$ of the total variance (Ownership). 
An interpretation of the five factors discussed above provides some clarification of the underlying structure of diversity within a university context. Diversity can be conceptualised as primarily consisting of respecting and valuing each other, irrespective of differences in background, race, gender, religion, age or culture. Secondary dimensions include conducting oneself in a manner sensitive to differences between colleagues, interacting and communicating openly with colleagues who are different from oneself, realising the impact that transformative initiatives have had on opportunities and performance, and taking ownership of managing diversity initiatives.

The reliability of the questionnaire was determined by means of Cronbach's alpha coefficients. The aim of the reliability analysis was to obtain initial estimates of reliability as a basis for scale purification, as well as to aid in optimising scale length. This analysis is concerned with providing evidence of internal consistency of the diversity scale for which the sample was appropriate in terms of providing accurate results. Coefficient alphas, item-total correlations and inter-item correlations were calculated for all items included within each sub-dimension. The acceptable benchmark level for item-total correlations was set at larger than 0.3 and the internal consistency of the sub-dimensions within each dimension was considered. Internal consistency reliability coefficients for the questionnaire scales, as measured by KuderRichardson Formula 8, ranged from 0.69 to 0.85 . Overall, the response rate secured sufficient observations to ensure a statistically valid analysis and the diversity questionnaire proved to be reliable with Cronbach's alpha values all above 0.69.

\section{Differences between workshop and non-workshop attendees}

In order to compare the differences between the workshop and non-workshop attendees, mean scores for each of the diversity dimensions and their respective items were calculated and are displayed in Table 4.

Table 4: Diversity item mean score by workshop attendees and non-attendees

\begin{tabular}{|c|c|c|c|c|c|c|}
\hline \multirow[t]{2}{*}{ Dimension } & \multirow[t]{2}{*}{$\begin{array}{l}\text { Cronbach } \\
\text { alpha }\end{array}$} & \multirow[t]{2}{*}{ Statement } & $\begin{array}{l}\text { Attendees } \\
(n=171)\end{array}$ & $\begin{array}{c}\text { Non- } \\
\text { attendees } \\
(n=90)\end{array}$ & \multirow[t]{2}{*}{$t$} & \multirow[t]{2}{*}{$\begin{array}{c}\text { Sig. } \\
\text { (2-tailed) }\end{array}$} \\
\hline & & & Mean & & & \\
\hline \multirow[t]{3}{*}{ Respect } & \multirow[t]{3}{*}{0.697} & $\begin{array}{l}\text { There is open } \\
\text { acceptance of all } \\
\text { dimensions of } \\
\text { human diversity } \\
\text { among Unisa staff } \\
\text { members* }\end{array}$ & 3.22 & 2.9 & 2.15 & 0.03 \\
\hline & & $\begin{array}{l}\text { People from all } \\
\text { backgrounds are } \\
\text { treated fairly at } \\
\text { Unisa* }\end{array}$ & 3.14 & 2.62 & 3.55 & 0 \\
\hline & & $\begin{array}{l}\text { Staff members } \\
\text { at Unisa are } \\
\text { comfortable } \\
\text { with other staff } \\
\text { members whose }\end{array}$ & 3.27 & 2.98 & 2.13 & 0.03 \\
\hline
\end{tabular}




\begin{tabular}{|c|c|c|c|c|c|c|}
\hline \multirow[t]{2}{*}{ Dimension } & \multirow[t]{2}{*}{$\begin{array}{l}\text { Cronbach } \\
\text { alpha }\end{array}$} & Statement & $\begin{array}{l}\text { Attendees } \\
(n=171)\end{array}$ & $\begin{array}{c}\text { Non- } \\
\text { attendees } \\
(n=90)\end{array}$ & $t$ & $\begin{array}{c}\text { Sig. } \\
\text { (2-tailed) }\end{array}$ \\
\hline & & $\begin{array}{l}\text { race/ethnicity is } \\
\text { different from their } \\
\text { own* } \\
\text { Staff members } \\
\text { are comfortable } \\
\text { with other staff } \\
\text { members whose } \\
\text { gender is different } \\
\text { from their own }\end{array}$ & 3.56 & 3.46 & 0.77 & 0.44 \\
\hline & & $\begin{array}{l}\text { Staff members } \\
\text { of different race/ } \\
\text { ethnic groups } \\
\text { are valued and } \\
\text { respected equally } \\
\text { at Unisa* } \\
\text { Staff members } \\
\text { of both genders } \\
\text { are valued and } \\
\text { respected equally } \\
\text { at Unisa }\end{array}$ & 3.42 & 3.22 & 1.44 & 0.15 \\
\hline & & $\begin{array}{l}\text { Staff members of } \\
\text { different religions } \\
\text { are valued and } \\
\text { respected equally } \\
\text { at Unisa }\end{array}$ & 3.63 & 3.42 & 1.52 & 0.13 \\
\hline & & $\begin{array}{l}\text { Staff members } \\
\text { of all ages are } \\
\text { valued and } \\
\text { respected equally } \\
\text { at Unisa* }\end{array}$ & 3.53 & 3.23 & 2.2 & 0.03 \\
\hline & & $\begin{array}{l}\text { Staff members of } \\
\text { different sexual } \\
\text { orientations } \\
\text { are valued and } \\
\text { respected equally } \\
\text { at Unisa* }\end{array}$ & 3.58 & 3.19 & 3.16 & 0 \\
\hline & & $\begin{array}{l}\text { Competence } \\
\text { is recognised } \\
\text { irrespective of } \\
\text { race* }\end{array}$ & 3.3 & 2.86 & 2.67 & 0.01 \\
\hline & & $\begin{array}{l}\text { There is respect } \\
\text { for different ethnic } \\
\text { cultures in my } \\
\text { workspace }\end{array}$ & 3.77 & 3.54 & 1.67 & 0.1 \\
\hline & & $\begin{array}{l}\text { Competence } \\
\text { is recognised } \\
\text { irrespective of } \\
\text { gender }\end{array}$ & 3.5 & 3.39 & 0.7 & 0.49 \\
\hline & & Staff in my work & 3.8 & 3.42 & 2.83 & 0.01 \\
\hline
\end{tabular}




\begin{tabular}{|c|c|c|c|c|c|c|}
\hline \multirow[t]{3}{*}{ Dimension } & \multirow[t]{3}{*}{$\begin{array}{l}\text { Cronbach } \\
\text { alpha }\end{array}$} & \multirow[t]{2}{*}{ Statement } & $\begin{array}{l}\text { Attendees } \\
(n=171)\end{array}$ & $\begin{array}{c}\text { Non- } \\
\text { attendees } \\
(n=90)\end{array}$ & \multirow[t]{2}{*}{$t$} & \multirow[t]{2}{*}{$\begin{array}{c}\text { Sig. } \\
\text { (2-tailed) }\end{array}$} \\
\hline & & & Mean & & & \\
\hline & & $\begin{array}{l}\text { environment } \\
\text { recognise } \\
\text { the value of } \\
\text { working with a } \\
\text { team of diverse } \\
\text { employees* } \\
\text { Competence } \\
\text { is recognised } \\
\text { irrespective of } \\
\text { religion }\end{array}$ & 3.89 & 3.84 & 0.35 & 0.73 \\
\hline \multirow[t]{5}{*}{ Conduct } & \multirow[t]{5}{*}{0.819} & $\begin{array}{l}\text { I have not been } \\
\text { treated differently } \\
\text { because of my } \\
\text { race while I have } \\
\text { worked at Unisa* }\end{array}$ & 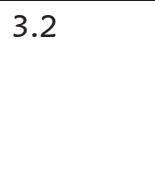 & 2.91 & 1.82 & 0.05 \\
\hline & & $\begin{array}{l}\text { I have not been } \\
\text { treated differently } \\
\text { because of my } \\
\text { gender while I } \\
\text { have worked at } \\
\text { Unisa* }\end{array}$ & 3.47 & 3.04 & 2.65 & 0.01 \\
\hline & & $\begin{array}{l}\text { I have not been } \\
\text { treated differently } \\
\text { because of my } \\
\text { sexual orientation } \\
\text { while I have } \\
\text { worked at Unisa }\end{array}$ & 3.5 & 3.51 & -0.09 & 0.93 \\
\hline & & $\begin{array}{l}\text { I have not been } \\
\text { treated differently } \\
\text { because of my } \\
\text { age while I have } \\
\text { worked at Unisa }\end{array}$ & 3.61 & 3.59 & 0.17 & 0.87 \\
\hline & & $\begin{array}{l}\text { I have not been } \\
\text { treated differently } \\
\text { because of my } \\
\text { religion while I } \\
\text { have worked at } \\
\text { Unisa }\end{array}$ & 3.68 & 3.67 & 0.08 & 0.94 \\
\hline \multirow[t]{2}{*}{ Interaction } & \multirow[t]{2}{*}{0.854} & $\begin{array}{l}\text { Colleagues in my } \\
\text { immediate work } \\
\text { team are talking } \\
\text { more openly } \\
\text { about diversity/ } \\
\text { cultural issues } \\
\text { than } 12 \text { months } \\
\text { ago* }\end{array}$ & 3.36 & 3.03 & 2.34 & 0.02 \\
\hline & & $\begin{array}{l}\text { Colleagues of } \\
\text { different race } \\
\text { groups interact } \\
\text { more positively } \\
\text { with one another }\end{array}$ & 3.43 & 3.12 & 2.34 & 0.02 \\
\hline
\end{tabular}




\begin{tabular}{|c|c|c|c|c|c|c|}
\hline \multirow[t]{3}{*}{ Dimension } & \multirow[t]{2}{*}{$\begin{array}{l}\text { Cronbach } \\
\text { alpha }\end{array}$} & \multirow[t]{2}{*}{ Statement } & $\begin{array}{l}\text { Attendees } \\
(n=171)\end{array}$ & $\begin{array}{c}\text { Non- } \\
\text { attendees } \\
(n=90)\end{array}$ & \multirow[t]{2}{*}{$t$} & \multirow[t]{2}{*}{$\begin{array}{c}\text { Sig. } \\
\text { (2-tailed) }\end{array}$} \\
\hline & & & Mean & & & \\
\hline & & $\begin{array}{l}\text { in a social context } \\
\text { than } 12 \text { months } \\
\text { ago* } \\
\text { Members of the } \\
\text { team(s) within } \\
\text { which I work } \\
\text { interact more } \\
\text { positively across } \\
\text { racial lines in a } \\
\text { social context than } \\
12 \text { months ago* }\end{array}$ & 3.58 & 3.16 & 3.33 & 0 \\
\hline & & $\begin{array}{l}\text { I interact more } \\
\text { effectively with other } \\
\text { race groups in the } \\
\text { work context than } 12 \\
\text { months ago* }\end{array}$ & 3.82 & 3.37 & 3.51 & 0 \\
\hline \multirow[t]{4}{*}{ Impact } & \multirow[t]{4}{*}{0.759} & $\begin{array}{l}\text { Affirmative action } \\
\text { contributes to the } \\
\text { success of Unisa* }\end{array}$ & 3.25 & 2.92 & 2.17 & 0.03 \\
\hline & & $\begin{array}{l}\text { The transformation } \\
\text { programme at } \\
\text { Unisa has resulted } \\
\text { in increased } \\
\text { opportunities for } \\
\text { me* }\end{array}$ & 2.85 & 2.31 & 3.33 & 0 \\
\hline & & $\begin{array}{l}\text { Diversity in } \\
\text { Unisa will } \\
\text { deliver superior } \\
\text { performance* }\end{array}$ & 3.84 & 3.41 & 3.05 & 0 \\
\hline & & $\begin{array}{l}\text { Appointmentsat } \\
\text { Unisa are based } \\
\text { on competence* }\end{array}$ & 2.98 & 2.39 & 3.94 & 0 \\
\hline \multirow[t]{3}{*}{ Ownership } & \multirow[t]{3}{*}{0.699} & $\begin{array}{l}\text { I personally } \\
\text { intervene in } \\
\text { diversity-related } \\
\text { matters* }\end{array}$ & 3.64 & 3.14 & 3.51 & 0 \\
\hline & & $\begin{array}{l}\text { I facilitate the } \\
\text { establishment of } \\
\text { good relationships } \\
\text { between different } \\
\text { ethnic groups }\end{array}$ & 3.91 & 3.74 & 1.94 & 0.25 \\
\hline & & $\begin{array}{l}\text { I take employment } \\
\text { equity issues } \\
\text { within Unisa into } \\
\text { account when }\end{array}$ & 3.94 & 3.93 & 0.02 & 0.99 \\
\hline
\end{tabular}




\begin{tabular}{|l|l|l|l|l|l|l|}
\hline Dimension & $\begin{array}{l}\text { Cronbach } \\
\text { alpha }\end{array}$ & Statement & $\begin{array}{l}\text { Attendees } \\
(\mathrm{n}=171)\end{array}$ & $\begin{array}{c}\text { Non- } \\
\text { attendees } \\
(\mathrm{n}=90)\end{array}$ & $t$ & $\begin{array}{c}\text { Sig. } \\
\text { (2-tailed) }\end{array}$ \\
\cline { 3 - 5 } & Mean & & \\
\cline { 3 - 5 } & $\begin{array}{l}\text { recommending an } \\
\text { appointment to my } \\
\text { superiors }\end{array}$ & & & \\
\hline
\end{tabular}

* Significant at a $95 \%$ level of confidence

Close inspection of Table 4 reveals that the largest differences between workshop attendees and non-attendees were apparent in the impact and interaction dimensions. The two items that differed most between the two groups were "appointments at Unisa are based on competence" and "the transformation programme at Unisa has resulted in increased opportunities for me", with workshop attendees agreeing significantly more with these statements. Other impact-related items concerned an expectation that diversity and affirmative action at Unisa will result in higher performance. This finding is in contrast to the assertion that affirmative action and employment equity targets do not lead to an organisational climate that embraces diversity as a strategic asset, compared to a political imperative. With regard to the interaction dimension, workshop attendees agreed significantly more than nonattendees that staff members interact more positively and communicate more openly than a year ago. Workshop attendees moreover agreed that people from all backgrounds, ethnic groups, sexual orientations and ages are treated fairly, respected and valued.

The workshops seem to have had little or no effect on statements involving respect for different cultures, religions, genders, age or sexual orientation, as both groups displayed a high level of agreement.

An examination of the mean differences between attendees and non-attendees reflected in Table 4 moreover reveals that the diversity-training interventions seem to be more conducive for influencing university staff to respect and value differences in background, race, sexual orientation and age. Conversely, the interventions seem to have had limited impact on dealing with cultural, gender and religious differences and actually facilitating diversity issues in the day-to- day management of diversity. These are key issues that need to be addressed in future diversity training at universities.

\section{Conclusion}

The aims of this article was firstly to statistically identify the underlying dimensions of diversity, and secondly to investigate the impact of capacity building workshops through a comparison of attendees and non-attendees.

The findings of the current study make several important contributions. Firstly, the underlying dimensions of diversity in a university environment were established. It is interesting to note that similar diversity constructs to those found in the private sector, were established, However, the composition of statements per dimension are different, and consequently the designation of the dimensions. Secondly, the impact of the capacity building workshops was investigated and the 
results indicated a number of significant behavioural differences between attendees and non-attendees.

An overview of the diversity concept within the context of coercive pressure on universities to conform to employment equity targets set out in national policy indicated that the implementation of diversity management is characterised by various developmental stages. The final stage involves employees creating a productive environment in which everybody feels valued, in which their talents are fully utilised and within which organisational goals are met. The ultimate test for the successful implementation of transformative diversity initiatives would be an employee mind shift towards the "learning-and-effectiveness" paradigm. This paradigm espouses to promote equal opportunity for all employees while acknowledging and valuing cultural differences among people. This paradigm for managing diversity allows the organisation to internalise differences among employees so that it learns and grows because of these differences.

The diversity concept, as perceived by middle management at Unisa, displays a conceptual structure that consists of collegiality in respecting and valuing each other, conduct in being sensitive to differences, communication and conversation with all staff irrespective of differences, commitment and cooperation in realising the value of initiatives to change and creativity in transforming and taking personal ownership of managing diversity.

The findings moreover indicate that the transformative initiatives in the form of diversity workshops have had a positive impact on management who attended these workshops.

This finding should be interpreted within the positive sentiment expressed by all managers (including non-attendees of workshops) surveyed, in other words, those that participated were even more positive having attended the workshops. This implies that staff members who attended workshops seem to be better equipped to deal with diversity issues, have better insights into diversity matters, are more tolerant towards and understanding of individual and group differences, and feel that diversity workshops have contributed to building a corporate culture that values diversity. Diversity-related aspects that could be considered in developing skills, competencies and actions to effectively deal with diversity and tolerance at Unisa include designing evaluation criteria for managing diversity, implementing affirmative action plans to deal with tokenism and recognising the complex and multidimensional nature of gender and cultural groups (stereotypes). Unisa should also continue presenting these workshops and should encourage attendance through communicating the successes of affirmative action initiatives to employees.

It is hoped that this article will trigger discussion among the leadership in higher education, nationally and in Africa, on how the agenda for transformation and ensuing diversity among university staff could be effectively managed to achieve the lofty goals and ideals that universities aspire to.

It is finally recommended that the university continue with workshops to sensitise academic, administrative and professional staff at middle-management level to 
the new realities of an increasing diverse workforce. It is also important that the university continuously conduct research on the implementation of diversity in the university to ensure sustainability of the impact of the diversity workshops.

\section{References}

Carnevale, A. P., and Stone, S. C. 1995. The American mosaic. New York: McGraw-Hill.

Cavaleros, C., Van Vuuren, L.J. and Visser, D. 2002. The effectiveness of a diversity awareness training programme. South African Journal of Industrial Psychology, 28(3): 50-61.

Düweke, L.D. 2004. The role of employment equity in gender equity. Unpublished masters' dissertation.Pretoria: University of South Africa.

Fabrigar, L. R., Wegener, D. T., MacCallum, R. C., and Strahan, E. J. 1999. Evaluating the use of exploratory factor analysis in psychological research.

Psychological Methods, 4(3): 272-299

Griggs, L. B. Valuing diversity: Where from . . . where to? In L.B. Griggs and L.L. Louw, eds. 1995. Valuing diversity: New tools for a new reality. New York: McGraw-Hill.

Havenga, A. J. 1993. Beyond affirmative action there is diversity. PRO Technida. 10(1): 9-17.

Human, L., Bluen, S. and Davies, R. 1999. Baking a new cake: How to succeed at employment equity. Johannesburg: Knowledge Resources (Pty) Ltd.

Johnson, S. J. 1995. The status of valuing and managing diversity in Fortune 500 service organizations: Perceptions of top human resource professionals. Academy of Human Resource Development (AHRD) Conference Proceedings, St. Louis, MO.

Kandola, R. and Fullerton, J. 1998. Diversity in action. London Wiltshire: Cronwell Press.

Kreitner, R. And Kinicki, A. 2007. Organizational behaviour. $7^{\text {th }}$ ed. New York: McGraw-Hill.

Morrison, A. M. 1992. The new leaders: Guidelines on leadership diversity in America. San Francisco: Jossey-Bass.

Nieuwmeijer, L. J. 2001. Conflict and peace research: South African realities and challenges. Pretoria: HSRC.

Roosevelt Thomas, R. 1990. From affirmative action to affirming diversity. Harvard Business Review. 90(2): 107-117.

Simons, G. F. ed. 1992. The questions of diversity: Assessment tools for organizations and 
individuals, 4th ed. Amherst, MA: ODT Incorporated. Republic of South Africa. 1998.

Employment Equity Act no 55, Pretoria: Government Printer. Available at < http://www.agsa.co.za/Portals/1/ACTS/ EEA.pdf > accessed 29 July, 2011.

Strydom, J. B. and Erwee, R. 1998. Diversity management in a South African University: A case study. Journal of Industrial Psychology, 24(2), 9-14.

Thomas, R. R., Jr. Managing diversity: A conceptual framework. In S. E. Jackson \&Associates eds. 1992, Diversity in the workplace. New York: Guilford Press. Thomas, D. and Ely, R. 1999. Making differences matter: A new paradigm for managing diversity. Harvard Business Review on Managing People, Boston: Harvard Business School Publishing.

Thompson, N. 1998. Promoting equality: Challenging discrimination and oppression in the human services, London: Macmillan.

Tjale, T. E. 2005. The relationship between diversity management and organisational climate. Unpublished masters' dissertation. Pretoria: University of South Africa.

Triandis, H. C. 1994. Culture and social behavior. New York: McGraw-Hill. Unisa. 2005. 2015 Strategic Plan: An agenda for transformation. Pretoria.

Velicer, W. F. and Jackson, D. N. 1990. Component analysis versus common factor analysis: Some issues in selecting an appropriate procedure. Multivariate Behavioral Research. 25: 1-28

Wheeler, M. L. 1994. Diversity training (Research Report Number 1083-94RR).

New York: The Conference Board. 